\title{
Pengaruh Back Rolling Massage dan Akupunktur Titik GB21 terhadap Produksi ASI Ibu Post Partum
}

\section{The Influence of Back Rolling Massage and Acupuncture Point GB21 towards Breast Milk Production of Post-partum Mothers}

\author{
Ekadewi Retnosari ${ }^{1}$, Nia Clarasari MP ${ }^{2}$ \\ ${ }^{1}$ Prodi DIII Kebidanan Muara Enim, Politeknik Kesehatan Kemenkes Palembang, Indonesia \\ ${ }^{2}$ Praktik Mandiri Bidan Wilayah Puskesmas Ujanmas, Kabupaten Muara Enim, Indonesia
}

\section{ARTICLE INFO}

\section{Article history}

Received date

26 Nov 2020

Revised date

9 Mar 2021

22 Mar 2021

Accepted date

8 April 2021

Keywords:

Acupuncture GB21 Back Rolling Massage; Breast milk production; Post-partum mothers.

\section{Kata kunci:}

Akupunktur GB21; Back rolling massage; Produksi ASI; Ibu nifas.

\author{
ABSTRACT/ ABSTRAK
}

\begin{abstract}
Early breastfeeding is an initial key to success in breastfeeding practice where breastmilk is given immediately 3 minutes after birth. Breastfeeding problems can appear, one of them, are caused by certain conditions. For instance, the mother complains on the first day of breast milk production and the ejection of it cannot get out or just a little bit, so it makes a worried the mother in giving breast milk. This is also compounded by the fussy condition of the baby's which makes mothers think that their breast milk is not enough to fulfill the baby's nutrition. It is no least of mothers who give formula milk to their babies and not to train their babies to suck mother's nipple. In a worrying condition and lack confidence feeling about insufficient breast milk, a mother needs help and support in producing breast milk. Some of the alternative efforts can be done to increase breast milk production either using pharmacology or non-pharmacology. A way in nonpharmacology is by doing the back rolling massage and acupuncture point GB21. This research was conducted to analyze the influence of back rolling massage and acupuncture point GB21 on breast milk production. The method was a quasi-experiment with pretestposttest with a control group design; the total sample was 90 post-partum mothers. The result showed there was a significant influence of weight after the research on the three groups (p-value 0,0001). The conclusion that back rolling massage and acupuncture point GB21 give an influence in increasing breast milk production.
\end{abstract}

\begin{abstract}
Menyusui dini merupakan kunci awal dari suksesnya praktik menyususi, dimana ASI diberikan segera dalam waktu 3 menit setelah lahir. Masalah menyusui yang dapat timbul salah satunya diakibatkan karena keadaan khusus, seperti ibu mengeluh pada hari pertama produksi ASI dan ejeksi ASI tidak keluar atau hanya keluar sedikit sehingga hal ini menyebabkan kecemasan atau kekhawatiran ibu akan ketidakmampuan dia untuk memberikan ASI. Ibu memerlukan bantuan dan dukungan untuk dapat mempertahankan produksi ASI. Upaya alternatif yang dapat dilakukan untuk meningkatkan produksi ASI dengan cara farmakologi maupun non farmakologi. Cara non farmakologi yang bisa dilakukan adalah back rolling massage dana pada titik GB21. Efek dari kedua terapi ini dapat memberikan kenyamanan dan mencegah stres pada Ibu. Hal ini sangat berpengaruh terhadap hormon prolaktin dan hormon oksitosin yang mempunyai peran penting dalam meningkatkan produksi ASI. Penelitian ini bertujuan untuk menganilisis Pengaruh back rolling massage dan akupunktur yitik GB21 terhadap produksi ASI. Metode dalam penelitian adalah Quasi Experimnet dengan desain pretest-posttest with control group, dengan total sampel 90 ibu nifas. Hasil uji statistik menunjukkan ada pengaruh yang bermakna berat badan setelah penelitian pada ketiga kelompok (p-value 0,000). Disimpulkan bahwa back rolling massage dan akupunktur titik GB21 memberikan pengaruh dalam peningkatan produksi ASI.
\end{abstract}

Corresponding Author:

Ekadewi Retnosari

Prodi DIII Kebidanan Muara Enim, Politeknik Kesehatan Kemenkes Palembang, Indonesia Email: ekadewiretnosari@gmail.com 


\section{PENDAHULUAN}

Air Susu Ibu (ASI) merupakan makanan tunggal terbaik yang diciptakan Allah dengan keunggulan yang tidak dapat digantikan oleh makanan dan minuman apapun karena mengandung zat gizi yang paling tepat, lengkap dan selalu menyesuaikan dengan kebutuhan bayi setiap saat (Astuti, 2017; Sari, 2017).

United Nations Children's Fund (UNICEF) menjelaskan bahwa tingginya Angka Kematian Bayi (AKB) di Indonesia dapat dicegah melalui pemberian ASI secara dini serta pemberian ASI saja sampai bayi berusia 6 bulan tanpa pemberian cairan apapun (Dewei, 2017).

Berdasarkan Peraturan Pemerintah RI Nomor 33 Tahun 2012 tentang pemberian ASI ekslusif bahwa setiap ibu yang melahirkan harus memberikan ASI eksklusif kepada bayi yang dilahirkannya. Semua ibu dapat dengan sukses menyusui diukur dari permulaan pemberian ASI dalam jam pertama kehidupan bayi. Menyusui menurunkan risiko infeksi akut seperti diare, pneumonia, infeksi telinga, haemophilus influenza, meningitis dan infeksi saluran kemih. Menyusui juga melindungi bayi dari penyakit kronis masa depan seperti diabetes tipe I serta kelebihan berat badan dan obesitas pada masa remaja dan dewasa (Florida, 2019).

Al-Qur'an Surah Al- Baqarah ayat 233 dijelaskan bahwa Allah memerintahkan kepada orang tua khususnya ibu untuk memberikan ASI eksklusif

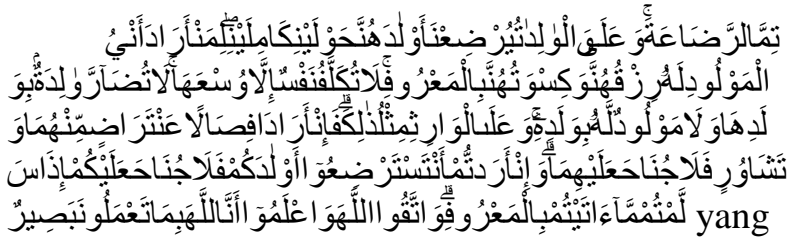
artinya "para ibu hendaklah menyusukan anakanaknya selama dua tahun penuh, yaitu bagi yang ingin menyempurnakan penyusuan. Dan kewajiban ayah memberi makan dan pakaian kepada para ibu dengan cara ma'ruf. Seseorang tidak akan dibebani melainkan menurut kadar kesanggupannya" (Departemen Agama, 2013).

Masalah pelaksanaan ASI eksklusif di Indonesia masih memprihatinkan. Kementerian Kesehatan menargetkan peningkatan pemberian ASI ekslusif hingga $80 \%$. Namun Pencapaian ASI Ekslusif di Indonesia masih 74,5\% (Balitbangkes, 2018). Berdasarkan data profil kesehatan Indonesia, cakupan ASI ekslusif tahun 2018 yaitu sebesar 68,74\%. Hasil Riskesdas Tahun 2018 mengungkapkan bahwa alasan utama anak $0-23$ bulan belum/tidak pernah disusui adalah karena ASI tidak keluar $(65,7 \%)$ sehingga
$33,3 \%$ bayi yang berumur di bawah 6 bulan telah diberikan makanan prelakteal dengan jenis makanan terbanyak adalah susu formula $(84,5 \%)$ (Yulita, 2020). Padahal, menyusui dini merupakan kunci awal dari suksesnya praktik menyusui, dimana ASI diberikan segera dalam waktu 3 menit setelah lahir. Masalah menyusui dapat pula diakibatkan karena keadaan khusus, ibu mengeluh pada hari pertama produksi ASI dan ejeksi ASI tidak keluar atau hanya keluar sedikit sehingga hal ini menyebabkan kecemasan atau kekhawatiran ibu akan pemberian ASI dan kondisi ini pula diperparah dengan keadaan bayi yang sedikit rewel sehingga banyak ibu yang berpikiran ataupun beranggapan bahwa ASI-nya tidak cukup untuk memenuhi kebutuhan nutrisi bayinya. Hai ini menyebabkan tidak sedikit ibu bayi yang memberikan susu formula pada bayinya dan tidak melatih bayinya untuk menghisap payudara ibu. Kondisi ibu yang penuh kekhawatiran dan rasa tidak percaya diri karena ASI nya tidak cukup ini memerlukan bantuan dan dukungan untuk dapat mempertahankan produksi ASI (Albertina, 2015; Lestari, 2018).

Upaya alternatif yang dapat dilakukan untuk meningkatkan produksi ASI dengan cara farmakologi maupun non farmakologi. Cara non farmakologi yang bisa dilakukan adalah back rolling massage dan akupunktur pada titik GB21. Efek dari kedua terapi ini dapat memberikan kenyamanan dan mencegah stres pada Ibu. Hal ini sangat berpengaruh dalam merangsang hormon prolaktin dan oksitosin yang mempunyai peran penting dalam meningkatkan Produksi ASI (Badrus, 2018; Kurniawan, 2019).

Hasil penelitian yang dilakukan oleh Elvika (2018, dalam Shanti, 2018) didapatkan hasil bahwa Back Rolling Massage sangat efektif dalam meningkatkan produksi ASI. Hal ini sangat terlihat dari perbedaan rerata berat badan bayi antara kelompok perlakuan dan kelompok kontrol. Kelompok perlakuan lebih besar di bandingkan kelompok kontrol. Begitu juga hasil penelitian yang dilakukan oleh Leny (2019, dalam Kurniawan, 2019) bahwa ada pengaruh yang signifikan terhadap produksi ASI pada pasien yang diberikan akupunktur titik GB21.

Tujuan penelitian ini adalah untuk menganalisis pengaruh back rolling massage dan akupunktur titik GB21 terhadap produksi ASI pada ibu nifas. Penelitian ini diharapkan secara praktis dapat digunakan sebagai bahan masukkan bagi pengelola pelayanan kesehatan terutama pelayananan kebidanan dalam upaya memberikan asuhan kebidanan yang berbasis bukti penelitian untuk dapat disebarluaskan serta dapat menjadi informasi bagi ibu nifas. 


\section{METODE}

Metode penelitian yang digunakan adalah quasi experiment dengan desain pretest-posttest with control group yang dilakukan pada 90 responden. Responden pada penelitian ini adalah ibu nifas yang bersalin di PMB Wilayah Puskesmas Ujanmas. Responden dibagi menjadi 3 kelompok yaitu kelompok perlakuan I dengan teknik back rolling massage sebanyak 30 responden, perlakuan II dengan Akupunktur Titik GB21 sebanyak 30 responden dan kelompok kontrol sebanyak 30 responden. Responden dengan perlakuan back rolling massage dilakukan pemijatan pada hari pertama dengan menggunakan baby oil selama 2-3 menit sebanyak 3 kali pemijatan yang dilakukan oleh bidan. Kelompok perlakuan II diberikan terapi akupunktur pada titik GB21 yang dilakukan oleh tenaga kesehatan yang sudah tersertifikasi pada hari pertama post partum. Jarum akupunktur akan ditusukkan pada titik GB21 sebanyak 1 jarum. Jarum ini akan dibiarkan tertancap selama 5 menit kemudian dirangsang dengan diputar-putar. Melalui perangsangan ini diharapkan sensasi jarum seperti rasa kesetrum. Bila sudah terasa berarti pengobatan yang diberikan mulai bereaksi. Lima menit kemudian dirangsang lagi dengan cara yang sama, kemudian dibiarkan selama lima menit. Begitu seterusnya sampai sekitar 30 menit untuk setiap tindakan. Penilaian produksi ASI dilihat pada hari kelima dan kesepuluh postpartum dengan mengukur berat bayi menggunakan timbangan bayi digital merk LAICA BF 2051 dengan ketelitian 10gram. Timbangan ini dilengkapi dengan fitur weightblockfunction dimana ukuran tetap stabil meskipun bayi bergerak-gerak.

Pengolahan dan analisa data menggunakan analisa univariat dan bivariat. Untuk analisa bivariat, uji yang digunakan adalah uji Anova bila sebaran datanya normal atau uji Kruskall Wallis jika data tidak berdistribusi normal, dan perbandingan rata-rata dua kelompok berpasangan yakni uji $\mathrm{t}$ bila sebaran datanta normal atau uji Wilcoxon jika data tidak berdistribusi normal.

Nilai $p$-value yang digunakan untuk menunjukkan kemaknaan adalah $<0,05$, sedangkan uji normalitas data menggunakan uji Shapiro Willk untuk $\mathrm{n}<50$, dengan ketentuan data berdistribusi normal jika $p$-value $>0,05$.

Penelitian ini telah mendapatkan Keterangan Lolos Kaji Etik (Ethical Approval) dari Komite Etik Penelitian Kesehatan Politeknik Kesehatan Kemenkes Palembang dengan Nomor 484.KEPK/Adm2/IX/2020.

\section{HASIL}

Tabel 1. Karakteristik Subjek Penelitian

\begin{tabular}{|c|c|c|c|c|}
\hline Variabel & Kontrol & Back Rolling Massage & Akupunktur GB21 & p-value \\
\hline \multicolumn{5}{|l|}{ Umur } \\
\hline$<20$ tahun & $12(40,0 \%)$ & $1(3,3 \%)$ & $13(43,3 \%)$ & 0,000 \\
\hline 20-35 ahun & $13(43,3 \%)$ & $28(93,3 \%)$ & $13(43,3 \%)$ & \\
\hline$>35$ tahun & $5(16,7 \%)$ & $1(3,3 \%)$ & $4(13,3 \%)$ & \\
\hline \multicolumn{5}{|l|}{ Pendidikan } \\
\hline SD & $2(6,7 \%)$ & $0(0,0 \%)$ & $2(6,7 \%)$ & 0,115 \\
\hline SMP & $7(23,3 \%)$ & $1(3,3 \%)$ & $8(26,7 \%)$ & \\
\hline SMA & $16(53,3 \%)$ & $19(63,3 \%)$ & $13(43,3 \%)$ & \\
\hline PT & $5(16,7 \%)$ & $10(33,3 \%)$ & $7(23,3 \%)$ & \\
\hline \multicolumn{5}{|l|}{ Pekerjaan } \\
\hline Bekerja & $8(26,7 \%)$ & $6(20,0 \%)$ & $5(16,7 \%)$ & 0,627 \\
\hline Tidak Bekerja & $22(73,3 \%)$ & $24(80,0 \%)$ & $25(83,3 \%)$ & \\
\hline \multicolumn{5}{|c|}{ Frekuensi Menyusui } \\
\hline$<8 \mathrm{kali} / \mathrm{hari}$ & 0 & 0 & 0 & - \\
\hline $8-12 \mathrm{kali} / \mathrm{hari}$ & $30(100 \%)$ & $30(100 \%)$ & $30(100 \%)$ & \\
\hline $12 \mathrm{kali} /$ hari & 0 & 0 & 0 & \\
\hline
\end{tabular}

Pada tabel 1 berdasarkan umur didapatkan kelompok kontrol paling banyak umur 20-35 tahun $(43,3 \%)$, kelompok back rolling massage lebih dari sebagian besar umur 20-35 tahun $(93,3 \%)$ dan kelompok akupunktur jumlah umur $<20$ tahun sama dengan umur $<20-35$ tahun $(43,3 \%)$. Hasil uji statistik didapatkan adanya perbedaan umur yang signifikan pada ketiga kelompok (p-value 0,002). Berdasarkan pendidikan didapatkan ketiga kelompok dalam penelitian ini sebagian besar dengan pendidikan SMA. Hasil uji statistik didapatkan tidak ada perbedaan pendidikan yang signifikan pada ketiga kelompok ( $p$-value 0,015). Pekerjaan, dari 
ketiga kelompok penelitian didapatkan sebagian besar tidak bekerja. Hasil uji statistik didapatkan tidak adanya perbedaan yang signifikan pekerjaan pada ketiga kelompok ( $p$-value 0,627 )
Berdasarkan frekuensi pemberian ASI didapatkan seluruh kelompok memberikan ASI sebanyak 812 kali/hari selama 10 hari.

Tabel 2. Analisis Berat Lahir pada Kelompok Back Rolling Massage dan Akupunktur Titik GB21 dan Kelompok Kontrol Sebelum Penelitian

\begin{tabular}{lrrrr}
\hline Berat Lahir & \multicolumn{1}{c}{ Kontrol } & Back Rolling Massage & Akupunktur GB21 & p-value \\
\hline Mean $(S D)$ & $2979,6(212,8)$ & $3230(455,7)$ & $2994,6(226,4)$ & 0,004 \\
Median & 2965,0 & 3300,0 & 3030,0 & \\
Minimum & 2660 & 2500,0 & 2500 & \\
Maximum & 3570 & 4300,0 & 3390 & \\
\hline
\end{tabular}

Tabel 2 didapatkan rata-rata berat badan lahir pada kelompok kontrol 2979,6 (212,8) gram, pada kelompok Back Rolling Massage $3230(455,7)$ gram, pada kelompok akupunkur
GB21 adalah 2994,6 (226,4) gram. Ada perbedaan yang bermakna berat badan sebelum penelitian (p-value 0,004).

Tabel 3. Uji Post Hoc untuk Menentukan Kelompok yang Memiliki Perbedaan Signifikan dari Tiga Kelompok Sebelum Penelitian

\begin{tabular}{llrrr}
\hline Kelompok & Kelompok & Mean Difference & Standart Error & p-value \\
\hline Kontrol & Back Rolling Massage & -250.333 & 82.232 & 0,009 \\
& Akupunktur & -15.000 & 82.232 & 1,000 \\
Back Rolling Massage & Kontrol & 250.333 & 82.232 & 0,009 \\
& Akupunktur & 235.333 & 82.232 & 0,016 \\
Akupunktur & Kontrol & 15.000 & 82.232 & 1,000 \\
& Back Rolling Massage & -235.333 & 82.232 & 0,016 \\
\hline
\end{tabular}

Tabel 3 hasil analisis menunjukkan adanya berbedaan bermakna pada kelompok Back Rolling Massage dengan kelompok kontrol ( $p$ value 0,009 ) dan kelompok back rolling massage dengan kelompok akupunktur (p-value 0,016). Sedangkan pada kelompok kontrol dan akupunktur tidak ada perbedaan yang bermakna (p-value 1,000).

Tabel 4. Analisis Berat Lahir pada Kelompok Back Rolling Massage dan Akupunktur Titik GB21 dan Kelompok Kontrol Setelah Penelitian

\begin{tabular}{lrrrr} 
Berat hari ke 10 & \multicolumn{1}{c}{ Kontrol } & Back Rolling Massage & Akupunktur GB21 & p-value \\
\hline Mean $(S D)$ & $2981,3(213,0)$ & $3418,67(402,75)$ & $3161,33(211,72)$ & 0,000 \\
Median & 2920,0 & 3450 & 3180,0 & \\
Minimum & 2670 & 2700 & 2700 & \\
Maximum & 3500 & 4300 & 3440 & \\
\hline
\end{tabular}

Tabel 4 didapatkan data hasil uji statistik menunjukkan ada perbedaan yang bermakna berat badan setelah penelitian pada ketiga kelompok (p-value 0,000) dimana kelompok back rolling massage memiliki rata-rata berat badan tertinggi setelah penelitian 3418,67 $(402,75)$ gram.

Tabel 5. Uji Post Hoc untuk Menentukan Kelompok yang Memiliki Perbedaan Signifikan dari Tiga Kelompok

\begin{tabular}{llrrr}
\hline Kelompok & Kelompok & Mean Difference & Standart ErroR & p-value \\
\hline Kontrol & Back Rolling Massage & -437.333 & 74.896 & 0,000 \\
& Akupunktur & -180.000 & 74.896 & 0,055 \\
Back Rolling Massage & Kontrol & 437.333 & 74.896 & 0,000 \\
& Akupunktur & 257.333 & 74.896 & 0,003 \\
Akupunktur & Kontrol & 180.000 & 74.896 & 0,055 \\
& Back Rolling Massage & -257.333 & 74.896 & 0,003 \\
\hline
\end{tabular}

Pada tabel 5 dilakukan analisis lanjut dengan uji post hoc untuk mengetahui kelompok mana yang mengalami perbedaan signifikan.
Hasil analisis menunjukkan adanya berbedaan bermakna pada kelompok back rolling massage dengan kelompok kontrol ( $p$-value 0,000) dan 
kelompok back rolling massage dengan kelompok akupunktur (p-value 0,003). Sedangkan pada kelompok kontrol dan akupunktur tidak ada perbedaan yang bermakna (p-value 0,055).

Tabel 6. Perbedaan Produksi ASI Pada Terapi Back Rolling Massage dan Akupunktur Titik GB21 Sebelum dan Setelah Penelitian

\begin{tabular}{lrrr}
\hline Kelompok & $\begin{array}{r}\text { Pre- } \\
\text { test }\end{array}$ & $\begin{array}{c}\text { Post- } \\
\text { test }\end{array}$ & $\begin{array}{c}\text { p- } \\
\text { value }\end{array}$ \\
\hline Kontrol & & & \\
Mean & 2979,6 & 2981,3 & $0,897 *$ \\
(SD) & $(212,8)$ & $(213,0)$ & \\
Median & 2965,0 & 2920,0 & \\
Minimum & 2660 & 2670 & \\
Maximum & 3570 & 3500 & \\
Back Rolling Massage & & \\
Mean & 3230 & 3418,67 & $0,000^{*}$ \\
(SD) & $(455,7)$ & $(402,75)$ & \\
Median & 3300,0 & 3450 & \\
Minimum & 2500,0 & 2700 & \\
Maximum & 4300,0 & 4300 & \\
Akupunktur & & & \\
Mean & 2994,6 & 3161,33 & $0,000 *$ \\
(SD) & $(226,4)$ & $(211,72)$ & \\
Median & 3030,0 & 3180,0 & \\
Minimum & 2500 & 2700 & \\
Maximum & 3390 & 3440 & \\
\hline
\end{tabular}

Tabel 6 pada kelompok kontrol tidak ada perbedaan bermakna sebelum dan setelah penelitian ( $p$-value 0,897). Pada kelompok Back Rolling Massage ada perbedaan bermakna sebelum dan setelah penelitian ( $p$-value 0,000 ). Pada kelompok akupunktur ada perbedaan bermakna sebelum dan setelah penelitian ( $p$ value 0,000$)$.

Tabel 7. Pengaruh Back Rolling Massage dan Akupunktur Titik GB21 terhadap Produksi ASI

\begin{tabular}{lrrrr}
\hline $\begin{array}{c}\text { Berat } \\
\text { hari ke } \\
\mathbf{1 0}\end{array}$ & Kontrol & $\begin{array}{c}\text { Back } \\
\text { Rolling } \\
\text { Massage }\end{array}$ & $\begin{array}{c}\text { Akupunk- } \\
\text { tur GB21 }\end{array}$ & $\begin{array}{c}\boldsymbol{p} \text { - } \\
\text { value }\end{array}$ \\
\hline Mean & 1,67 & 188,7 & 166,67 & $0,000^{*}$ \\
$($ SD) & $(67,6)$ & $(132,7)$ & $(69,6)$ & \\
Median & 0,00 & 200,0 & 170,0 & \\
Minimum & -160 & 0,00 & 40 & \\
Maximum & 250 & 500 & 700 & \\
\hline
\end{tabular}

Berdasarkan tabel 7 didapatkan rata-rata selisih berat badan pada kelompok kontrol 1,67 $(67,6)$ gram, pada kelompok Back Rolling Massage 188,7 (132,7) gram, pada kelompok Akupunkur GB 21 adalah 166,67 $(69,6)$ gram. Hasil uji statistik menunjukkan ada perbedaan yang bermakna berat badan setelah penelitian pada ketiga kelompok ( $p$-value 0,000).

Tabel 8. Pengaruh Produksi ASI Back Rolling Massage dan Akupunktur Titik GB21

\begin{tabular}{llrrr}
\hline \multicolumn{1}{c}{ Kelompok } & \multicolumn{1}{c}{ Kelompok } & $\begin{array}{c}\text { Mean } \\
\text { Difference }\end{array}$ & $\begin{array}{c}\text { Standard } \\
\text { Error }\end{array}$ & p-value \\
\hline Kontrol & Back Rolling Massage & $-121,667$ & 45,615 & 0,027 \\
& Akupunktur & 21,333 & 45,615 & 1.000 \\
Back Rolling Massage & Kontrol & 121,667 & 45,615 & 0,027 \\
& Akupunktur & 143,000 & 45,615 & 0,007 \\
Akupunktur & Kontrol & $-21,333$ & 45,615 & 1,000 \\
& Back Rolling Massage & $-143,000$ & 45,615 & 0,007 \\
\hline
\end{tabular}

Pada tabel 8 dilakukan uji post hoc untuk mengetahui kelompok mana yang terdapat perbedaan signifikan. Hasil analisis menunjukkan adanya perbedaan bermakna pada kelompok Back Rolling Massage dengan kelompok Akupunktur ( $p$-value 0,007). Terdapat perbedaan kelompok back rolling massage dengan kelompok kontrol ( $p$-value 0,027). Sedangkan pada kelompok akupunktur dan kelompok kontrol tidak ada perbedaan yang signifikan $(p$ value 1,000$)$.

\section{PEMBAHASAN}

\section{Karakteristik Subjek Penelitian}

Pada penelitian ini setiap kelompok, paling banyak adalah pada rentang umur 20-35 tahun. Hasil uji statistik didapatkan adanya perbedaan umur yang signifikan pada ketiga kelompok ( $p$ value 0,002 ).

Sesuai dengan teori yang menyatakan bahwa umur ibu memengaruhi sistem reproduksi. Ibu yang berada pada rentang usia reproduktif dapat lebih siap karena organ tubuh telah matang. Ibu yang muda akan lebih berisiko karena tubuhnya sendiri sedang mengalami perkembangan sedangkan pada ibu yang lebih tua organ reproduksi telah menurun sehingga 
berisiko terhadap kemampuan dalam proses reproduksI (Donal, 2013).

Berbeda dengan penelitian Saraung (2017) yang menjelaskan bahwa faktor yang memengaruhi produksi ASI adalah bentuk dan kondisi puting susu dengan produksi ASI nilai $p$ value $=0,030<\alpha=0,05$.

Menurut pendapat peneliti, meskipun terdapat perbedaan bermakna pada kelompok umur diharapkan hal ini tidak ada pengaruh terhadap pengeluaran produksi ASI karena dari kajian penelitian-penelitian sebelumnya umur tidak selalu memengaruhi produksi ASI. Oleh sebab itu penelitian ini dapat dilanjutkan tanpa harus melakukan analisis multivariat dengan umur sebagai factor confounding.

Dalam penelitian ini didapatkan pendidikan pada ketiga kelompok sebagian besar adalah SMA. Hasil uji statistik didapatkan tidak ada perbedaan pendidikan yang signifikan pada ketiga kelompok ( $p$-value 0,015).

Pendidikan merupakan proses menumbuh kembangkan seluruh kemampuan dan perilaku manusia melalui pengetahuan. Tingkat pendidikan yang semakin tinggi akan membuat pengetahuan seseorang menjadi lebih baik. Pendidikan yang baik akan memperoleh pengalaman yang diterima oleh pemikiran yang kritis sehingga akan dapat menambah wawasan (Notoadmodjo, 2015).

Penelitian Dardiana (2014) menyatakan bahwa pendidikan dapat memengaruhi ibu menyusui ( $p$-value $<0,05)$. Hal ini yang dimaksud adalah kemampuan teknik menyusui yang benar sehingga produksi ASI akan dapat berjalan dengan baik dan lebih banyak (Dardiana, 2014). Kondisi ini menunjukan bahwa faktor-faktor yang memengaruhi praktik menyusui tidak hanya dari pendidikan saja, namun dapat dipengaruhi faktor lain.

Berdasarkan pekerjaan didapatkan dari ketiga kelompok penelitian sebagian besar tidak bekerja. Hasil uji statistik didapatkan tidak adanya perbedaan yang signifikan pekerjaan pada ketiga kelompok ( $p$-value 0,627 ).

Faktor pekerjaan juga memengaruhi kemandirian ibu dalam mengambil keputusan, hal ini dikaitkan dengan sosial budaya. Ada kenaikan tingkat partisipasi wanita dalam lingkaran kerja dan adanya emansipasi dalam segala bidang kerja menyebabkan ibu mandiri. (Notoadmodjo, 2015)

Dalam penelitian Okawary (2015) faktor pekerjaan dapat memengaruhi pemberian ASI eksklusif pada bayi. Ibu bekerja biasanya mengalami kesulitan dalam pemberian ASI, ketika mulai kembali bekerja maka anak akan dititipkan kepada mertua dan akan diberikan ASI bila bayi menangis.

Menurut pendapat peneliti, pekerjaan belum berpengaruh terhadap penelitian ini. Hal ini karena penelitian dilakukan pada 10 hari pertama masa nifas sedangkan ibu bekerja akan mendapatkan cuti pada masa penelitian ini. Ditambah pada penelitian ini sebagian besar adalah ibu yang tidak bekerja oleh sebab itu pekerjaan tidak menjadi faktor confounding dalam penelitian ini.

Berdasarkan frekuensi pemberian ASI didapatkan seluruh kelompok memberikan ASI sebanyak 8-12 kali/hari selama 10 hari. Pemberian ASI pada bayi sebaiknya tidak dijadwalkan. Bayi disusui sesuai dengan permintaan bayi (on demand). Pada umumnya bayi yang sehat akan menyusui 8-12 kali perhari dengan lama menyusui 15-20 menit pada masingmasing payudara (Soetjiningsih, 2011; Suradi, 2014).

Frekuensi menyusui juga merupakan hal yang berpengaruh pada peningkatan berat badan bayi, semakin tinggi frekuensi menyusu maka bayi mendapat gizi yang lebih optimal sehingga berat badannya meningkat (Suradi, 2014)

Sejalan dengan penelitian Angriani (2018) menunjukkan bahwa frekuensi menyusui berhubungan dengan kelancaran produksi ASI ibu dengan nilai $p$-value $=0,019 \quad \mathrm{PR}=2,438$ (95\%CI 1,261-4,711). Setiap bayi mempunyai pola menyusu yang unik, tidak sama satu diantara yang lain, beberapa bayi biasanya mengisap sedikit atau hanya sebentar akan tetapi dengan frekuensi yang sering. Beberapa bayi juga menyusu lebih lama namun dengan frekuensi yang jarang. Pengisapan anak mempunyai peranan penting dalam produksi Air Susu Ibu karena memiliki pengaruh dalam pengeluaran hormon pituirin. Isapan anak akan merangsang otot polos yang terdapat dalam buah dada untuk berkontraksi yang kemudian merangsang susunan syaraf di sekitarnya dan meneruskan rangsangan ini ke otak. Otak akan memerintahkan kelenjar hypophyse bagian belakang untuk mengeluarkan pituirin lebih banyak, akan mempengaruhi kuatnya kontraksi otot-otot polos buah dada dan uterus. Kontraksi otot-otot polos pada buah dada berguna untuk pembentukan air susu ibu (Angriani, 2018).

Menurut pendapat peneliti frekuensi menyusui ketiga kelompok sudah sesuai yaitu dengan frekuensi 8-12 kali/sehari sehingga dapat meningkatkan kelancaran produksi ASI. 


\section{Back Rolling Massage}

Pada kelompok Back Rolling Massage berat badan lahir pada akhir penelitian yaitu terdapat pengaruh bermakna sebelum dan setelah penelitian ( $p$-value 0,000). Penelitian ini membandingkan hasil dari Back Rolling Massage, akupunktur pada titik GB21 dan kelompok kontrol terhadap produksi ASI.

Produksi ASI pada penelitian ini dilihat dari peningkatan berat badan bayi di akhir penelitian. Produksi ASI cukup atau tidak bisa dilihat dari berbagai indikator, seperti: perubahan berat badan, jumlah BAK, dan Jumlah BAB. Tanda yang paling dapat dipercaya adalah pertambahan berat badan bayi. Produksi ASI akan "berlimpah" pada hari kedua sampai hari keempat setelah melairkan. Tanda-tanda bahwa bayi cukup menerima ASI yang ditransfer melalui kegiatan menyusui adalah pertambahan berat. Bila bayi bertambah berat badan hanya dengan ASI, maka bayi mendapat cukup minum ASI. Penurunan berat badan bayi digunakan juga sebagai penanda asupan yang tidak memadai akibat dari pasokan susu yang tidak mencukupi.

Penelitian ini sejalan dengan penelitian Shanti (2018) dimana pada penelitiannya menunjukkan bahwa ada perbedaan yang bermakna $(p$-value $=0.023<0,05)$ produksi ASI (berat badan bayi) antara kelompok kontrol $(2687,07 \pm 160,155)$ dengan kelompok perlakuan teknik back rolling massage $(2846,13 \pm 198,968)$. Perbedaan ini terlihat pada rerata berat badan bayi pada kelompok perlakuan lebih besar dibandingkan dengan kelompok kontrol. Selain memperlancar ASI, back rolling massage juga memberikan kenyamanan pada ibu nifas, mengurangi bengkak (engorgement), mengurangi sumbatan ASI, merangsang pelepasan hormon oksitosin, mempertahankan produksi ASI ketika ibu dan bayi sakit (Shanti, 2018).

Menurut teori, Back Rolling Massage adalah pijat punggung untuk merangsang refleks oksitosin atau refleks let down. Pijat ini dilakukan dengan cara memijat pada daerah punggung sepanjang kedua sisi tulang belakang sehingga diharapkan ibu akan merasa rileks dan kelelahan setelah melahirkan akan hilang. Jika ibu rileks dan tidak kelelahan dapat membantu merangsang pengeluaran hormon oksitosin dan akan membantu pengeluaran air susu ibu (Astuti, 2017).

Back rolling massage akan menyebabkan terjadinya rangsangan di korda spinalis yang mana berfungsi sebagai penghubung saraf antara otak dan sistem saraf perifer. Semua komunikasi ke atas dan ke bawah korda spinalis terletak di jaras-jaras (traktus) asendens yang menyalurkan sinyal dari masukan aferen ke otak. Substansia grisea yang terletak di tengah korda spinalis mengandung penghubung antar neuron yang terletak antara masukan aferen dan keluaran eferen serta badan sel neuron eferen. Serat aferen dan eferen yang masing-masing membawa sinyal ke dan dari korda spinalis, menyatu menjadi saraf spinalis. Saraf-saraf ini melekat ke korda spinalis berpasangan di sepanjang korda. Neuron inhibitorik dan neuron kolimergik eksitatorik membuat kontak sinaps dengan neuron oksitosin neuro sekretorik di nucleus paraventrikularis dan supraoptikus. Kemudian hipotalamus memproduksi hormon oksitosin dan dialirkan menuju hipofisis posterior. Oksitosin menuju ke payudara maka dikeluarkannya hormon oksitosin. Hormon oksitosin inilah yang berpengaruh terhadap meningkatkan refleks let down (Greenstein, 2011).

Penelitian ini sejalan dengan Mayangsari (2020) dalam penelitiannya tentang back rolling massage yang menggunakan uji korelasi Paired Samples Test maka didapatkan hasil p-value sebesar $0,000<0,05$. Didukung oleh penelitian Shanti (2018) menunjukkan bahwa ada perbedaan yang bermakna ( $p$-value $=0.023<0,05$ ) produksi ASI (berat badan bayi) sebelum dan sesudah dilakukan Back Rolling Massage. Pemijatan merupakan salah satu terapi pendukung yang efektif untuk mengurangi ketidaknyamanan fisik serta memperbaiki gangguan mood. Pengurangan ketidaknyamanan pada ibu menyusui akan membantu lancarnya pengeluaran ASI (Shanti, 2018).

\section{Akupunktur Titik GB21}

Pada penelitian ini kelompok akupunktur memiliki rata-rata berat badan tertinggi kedua. Hasil analisa didapatkan bahwa ada pengaruh bermakna sebelum dan setelah penelitian ( $p$ value 0,000$)$.

Titik akupunktur yang digunakan adalah GB21. Menurut teori penggunaan akupunktur adalah cara pengobatan dengan cara menusukkan jarum khusus ke dalam titik-titik tertentu pada kulit yang dinamakan titik-titik akupunktur (acupoint) dan secara harfiah akupunktur berasal dari istilah asing, acus berarti jarum dan to puncture berarti tusukan (Saputra, 2005; Gondo, 2009).

Titik akupunktur GB21 merupakan titik meridian kandung empedu dan terdapat cabang saraf nervus supraklavikuler di bagian dalam terdapat nervus dorsalis skapulae, lokasi penusukan pada daerah pundak, di tengah-tengah antara acromio-claviculae dan vertebra cervical VII. Cara penjaruman tegak lurus sedalam 0,5 
cun. Penusukan pada titik GB21 dapat mengaktifkan daerah periaqueductal (PAG) dan nukleus rafe magnus (NRM) serta meningkatkan endorfin dan enkefalin dalam jumlah signifikan sehingga dapat meningkatkan hormon prolaktin dan merelaksasikan ibu saat menyusui (Chang, 2012).

Sejalan dengan penelitian yang dilakukan Kurniawan (2019) pemberian titik akupunktur ST18, GB21, dan CV17 dapat secara signifikan meningkatkan volume ASI pada ibu menyusui. Hal ini dapat dilihat responden yang volume ASI-nya 100-300ml/hari yaitu sebanyak 3 orang (20\%), volume ASI $300-500 \mathrm{ml} / \mathrm{hari}$ yaitu sebanyak 4 orang (27\%) dan $500-700 \mathrm{ml} /$ hari yaitu sebanyak 2 orang (20\%). (Kurniawan, 2019).

Berbeda dengan penelitian Machmudah (2020) yang menyatakan bahwa produksi ASI tergantung dari hormon prolaktin. Kelompok yang mendapat akupunktur titik GB21 memiliki perbedaan skor hormon prolaktin yang lebih rendah setelah hari ke Sembilan penelitian yaitu dari 2,95 menjadi 2,47. Hal ini dikarenakan ibu pada hari kesembilan berisiko kelelahan dalam merawat bayi sehingga kadar prolaktin lebih rendah (Machmudah, 2020).

Pada penelitian ini kelompok akupunktur mendapatkan penambahan berat badan pada hari kesepuluh meskipun menggunakan jarum akupunktur. Terdapat beberapa efek samping yang dirasakan ibu seperti ketidaknyamanan pada saat penusukan dan bekas kemerahan setelah penusukan tentunya membuat ibu tidak nyaman.

Stimulasi pada titik akupunktur dapat mengaktifkan tiga pusat yaitu spinal cord, midbrain dan hipofisis untuk melepaskan neurokimia seperti endorfin, serotin dan norepinephrin yang mampu memblok pesan nyeri. Titik akupunktur GB21 merupakan titik meridian kandung empedu dan terdapat cabang saraf nervus supraklavikuler di bagian dalam terdapat nervus dorsalis skapulae, lokasi penusukan pada daerah pundak, di tengah-tengah antara acromio-claviculae dan vertebra cervical VII. Cara penjaruman tegak lurus sedalam 0,5 cun. Keistimewaannya adalah titik pertemuan meridian kandung empedu dengan meridian lambung, meridian sanjiao dengan meridian yangwei. Penusukan pada titik GB21 dapat mengaktifkan daerah periaqueductal (PAG) dan nukleus rafe magnus (NRM) serta meningkatkan endorfin dan enkefalin dalam jumlah signifikan sehingga dapat meningkatkan hormon prolaktin dan merelaksasikan ibu saat menyusui. Jarum akupunktur akan ditusukkan pada titik GB21. Jarum ini akan dibiarkan tertancap selama 5 menit kemudian dirangsang dengan diputar-putar.
Dengan perangsangan ini diharapkan sensasi jarum seperti rasa kesetrum dan memerah disekitar penusukan. Bila sudah terasa berarti pengobatan yang diberikan mulai bereaksi. Lima menit kemudian dirangsang lagi dengan cara yang sama, kemudian dibiarkan selama lima menit. Begitu seterusnya sampai sekitar 30 menit untuk setiap terapi. Hal ini tentunya membuat ibu merasa tidak nyaman pada saat penusukan (Chang, 2012).

Pada penelitian ini kelompok kontrol hanya bertambah berat 1gram pada akhir penelitian. Hal ini menjunjukkan terdapat subjek penelitian yang berat badannya belum kembali pada akhir penelitian. Mayoritas penurunan berat badan pada bayi sebesar 5\%-7\% dari berat badan lahir, hari kedua dan ketiga setelah kelahiran merupakan kehilangan berat badan maksimal. Sebagian besar bayi mencapai berat badan lahir mereka dalam dua minggu pertama kelahiran (Wijayanti, 2016).

Menurut pendapat peneliti, terapi yang paling efektif dalam meningkatkan produksi ASI adalah dengan memberikan back rolling massage. Hali ini dapat dilakukan oleh orang yang sudah dilatih dan tidak harus tenaga kesehatan, keluarga yang telah mendapat pendidikan kesehatan dari bidan pun dapat melakukannya. Penggunaan back rolling massage dapat meningkatkan produksi ASI. Pada kelompok akupunktur juga dapat meningkatkan produksi ASI, namun penggunaanya harus dari tenaga ahli terlatih dan ibu harus siap dengan efek sampingnya. Sedangkan pada kelompok kontrol yang hanya mendapatkan pendidikan kesehatan saja sudah kembali ke berat lahir pada hari kesepuluh yang berarti bahwa telah sesuai dengan teori kembalinya berat lahir.

\section{SIMPULAN}

Terdapat perbedaan umur yang signifikan pada ketiga kelompok, namun tidak ditemukan perbedaan yang signifikan pada variabel pendidikan dan pekerjaan pada ketiga kelompok. Seluruh kelompok memberikan ASI sebanyak 8$12 \mathrm{kali} /$ hari selama 10 hari.

Ada perbedaan rata-rata berat badan lahir sebelum dan sesudah penelitian, dimana kelompok back rolling massage memiliki ratarata berat badan tertinggi setelah penelitian.

Hasil uji statistik menunjukkan ada pengaruh yang bermakna berat badan setelah penelitian pada ketiga kelompok sehingga dalam penelitian ini Back Rolling Massage lebih efektif dalam meningkatkan produksi ASI. 


\section{DAFTAR PUSTAKA}

Albertina, M. (2015). Hubungan Pijat oksitosin dengan Kelancaran Produksi ASI Pada Ibu Post Partum Seksio Sesarea hari Ke 2-3. Jurnal Husada Mahakam, 3(9), 452-522.

Angriani, R. (2018). Hubungan Frekuensi Menyusui dengan Kelancaran Produksi ASI Ibu Post Partum di Wilayah Kerja Puskesmas Peusangan Selatan Kabupaten Bireun Provinsi Aceh Tahun 2017. Jurnal Muara Sains, Edisi 1, 299-304.

Astuti, R. P., Rusmil, K., Permadi, W., Mose, J. C., Effendi, J. S., \& Herawati, D. M. (2017). Pengaruh Pijat Punggung dan Memerah ASI terhadap Produksi ASI pada Ibu Postpartum dengan Seksio Sesarea. Jurnal Pendidikan dan Pelayanan Kebidanan Indonesia, 2(1), 1-8.

Badrus, A. R. (2018). Perbedaan Massage Woolwich dan Massage Rolling (Punggung) Terhadap peningkatan Produksi ASI Pada Ibu Postpartum. Jurnal Ilmiah-J-HESTECH, 1(1), 43-49.

Balitbangkes. (2018). Laporan Nasional Rikesdas. Kemenkes RI.

Chang, S. (2012). The meridian system and mechanism of acupuncture-a comparative review. Part 1: the meridian system. Taiwanese Journal of Obstetrics and Gynecology, 51(4), 506-514.

Dardiana, A. E. (2014). Hubungan antara Pendidikan, Pekerjaan dan Pengetahuan Ibu dengan Tekhnik Menyusui yang Benar di Desa Leteh Kecamatan Rembang Kabupaten Rembang. Jurnal Kebidanan, 3 (2), 20-25.

Departemen Agama. (2013). Al-Quran dan Terjemahannya. Jakarta: Bumi Restu.

Dewei, A. P. S., Dasuki, D., \& Kartini, F. (2017). Efek Pijat Punggung terhadap Produksi Asi Pada Ibu Pasca Bedah Sesar. Jurnal Kesmas Indonesia, 9(2), 1-9.

Greenstein B., Diana W. (2011). Hormon Oksitosin . Jakarta: Erlangga.

Donal, M. (2013). Maye's Midwifery. Totonto: Elsevier.

Florida, G. N. (2019). Efektifitas Pijat Punggung,Pijat Oksitosin dan Kombinasi terhadap Produksi ASI Pada Ibu Dengan Section Caesarea. Jurnal keperawatan dan Kesehatan MEDISINA AKPER YPIB Majalengka, 5(9). 1-9.

Gondo, H. K. (2009). Peran Akupunktur Dalam Obstetri. Jurnal Ilmiah Kedokteran wijaya kusuma, 48-56.
Kurniawan, L. C. (2019). Pengaruh Titik Akupunktur ST 18,GB21,CV17 Terhadap Peningkatan Volume ASI Ibu Menyusui. Jurnal Kesehatan Hesti Wira Sakti, 7(1), 25-32.

Lestari, L. (2018). Peningkatan Pengeluaran ASI Dengan Kombinasi Pijat Oksitosin dan Teknik Marmet Pada Ibu Post Partum. Jurnal Kebidanan, 8(2), 120-129.

Machmudah. (2020). Improvement Of Prolactin Hormone Level On Postpartum Mother Taken By The Oketani Massage and Presure. Indonesian Journal Of Nursering Practices , 4(1), 1-6.

Mayangsari, D., \& Hidayati, S. N. (2020). Manfaat Rolling Massage Punggung Dan Endhorphin Massage Terhadap Produksi ASI. Jurnal Ilmu Keperawatan dan Kebidanan, 11(2), 162-167.

Notoadmodjo, S. (2015). Ilmu prilaku Kesehatan. Jakarta: Rineka.

Okawary, O. (2015). Hubungan Status Pekerjaan Ibu dengan Pemberian ASI Eklusif di Wilayah Kerja Puskesmas Seyegan Sleman Yogyakarta. [Skripsi]. Yogyakarta: Program Studi Ilmu Keperawatan, STIKES Aisyah Yogyakarta.

Shanti, E. F. (2018). Efektifitas Produksi ASI pada Ibu Post Partum Dengan Massage Rolling ( Punggung). Midwifery Journal, 3(1), 76-80.

Saputra. (2005). Akupunktur Dasar. Surabaya: Airlangga University Press.

Saraung, M. W. (2017). Analisis Faktor-Faktor Yang Berhubungan dengan Produksi ASI Pada Ibu Post Partum Di Puskesmas Ranatona Weru. Jurnal Keperawatan Unsrat, 5(2).1-8.

Sari, W. A. (2017). Pengaruh Perawatan Payudara Dengan Teknik Massage Rolling Pada Ibu Hamil Trimester III Terhadap kelancaran Pengeluaran ASI Postpartum Di Wilayah Kerja Puskesmas Perumnas II Pontianak Barat. Proners Journal. 3(1). 1-10.

Soetjiningsih. (2011). ASI: Petunjuk Untuk Tenaga Kesehatan. Bandung: Refika Aditama.

Suradi. (2014). Manajemen Laktasi. Jakarta: Perinesia .

Wijayanti, T. A. (2016). Efektifitas Breas Care Postpartum Terhadap Produksi ASI. Jurnal Kebidanan, 8(02). 201-208.

Yulita, N. J. (2020). Perilaku Ibu Nifas Dalam Meningkatkan produksi ASI. Jurnal Ilmiah kebidanan, 7(1), 53-61. 